\title{
IAMJ
}

INTERNATIONAL AYURVEDIC MEDICAL JOURNAL

\section{STABILITY STUDY OF MODIFIED MUSTA-TRIPHALADIAVALEHA WITH RESPECT TO BASELINE MICROBIAL PROFILE USED IN THALASSEMIA MAJOR}

\author{
Bhumi Mori $^{1}$, Cholera Mira ${ }^{2}$, K. S. Patel ${ }^{3}$, V. K. Kori ${ }^{4}$ \\ ${ }^{1} \mathrm{PhD}$ Scholar, ${ }^{2} \mathrm{Head}$, Microbiology Lab Professor; ${ }^{3}$ H.O.D., ${ }^{4}$ Assistant Professor., \\ IPGT \&amp; RA, Jamnagar, Gujarat, India
}

Corresponding Author: bhumori.bm@gmail.com

https://doi.org/10.46607/iamj0208102020

(Published online: October 2020)

Open Access

(C) International Ayurvedic Medical Journal, India 2020

Article Received: 04/09/2020 - Peer Reviewed: 27/09/2020 - Accepted for Publication: 29/09/2020

Check for updates

\begin{abstract}
Introduction: stability study of Modified Musta-Triphaladi Avaleha was done for 12 months (1 year) to know the stability of formulation in reference of its phyto-constituents and microbial growth therein. Modified MustaTriphaladi Avaleha have been used in Thalassemia children as an adjuvant therapy prepared with various herbal product. Methods: Modified Musta-Triphaladi Avaleha was made in Pharmacy with standard classical method (Avaleha Kalpana) as per AFI part-1 (The Ayurvedic formulary of India, part-1 part- A) In present study, stability with respect to its Microbial profile of Modified Musta-Triphaladi Avaleha carried out. Avaleha was stored in 2 plastic containers during different climatic condition. Avaleha were studied at regular intervals for a period of 1 month to analysis Mycological findings and presence of Microorganisms by wet mount preparation and Gram stain test respectively. Results: At the end of study both Avaleha container has not present of microbes after 1 year of preparation, even in different climate and temperature. Conclusion: Since it is traditional Avaleha kalpana, the shelf life period was about one year (Sharangdhar Samhita) The presented study reflects that Microbiological findings of Modified Musta-Triphaladi Avaleha was negative at room temperature, warm and cold, dry and humid condition.
\end{abstract}


Keywords: Microbial profile, Modified Musta-Triphaladi Avaleha, Climate condition, Stability.

\section{INTRODUCTION}

Thalassemia is a monogenic disorder characterized by abnormal synthesis of hemoglobin due to defects in the globin chain. This causes early excessive destruction of red blood cells leading to hypochromic, microcytic anemia, In Ayurvedic authentic texts, it cannot be found a disease similar to Thalassemia. But the methodology of understanding the unknown disease has been mentioned in Charaka Samhital based on Aaptopadesha Pramana (Authoritative instruction). An effort has been made to correlate Thalassemia major with Beejadushtijanya Pandu.(Thalassemia Major) An ideal drug to treat Thalassemia should have Deepana (Appetizer), Aamapachana (Digestion of immature juice of food), Srotovishodhana (Opening of cir- culating micro channels), Tridoshahara, Rochana (Relish), Jwarahara (Antipiretic), Pittasaraka (Pitta excretor), Lohashodhana (Iron purifier from body), Lohamarana (Iron Cheltor), Lekhana (Scraping), Bhedana (Purgative), Raktashodhana (Blood Purifier), Raktaprasadana (Blood nutritive), Shonitasthapana (Haemostasis), Varnya (Glowing body complexion), Balya (Strengthen Drug), Brimhana (Anabolic), Rasayana (Enhance longevity \&delays ageing) and Vayahasthapana (Age Prolonger) properties. Modified Musta-Triphaladi Avaleha is such a combination of all properties. Avaleha is a Good palatable drug for child.

Table 1: Ingredients of Modified Musta-Triphaladi Avaleha

\begin{tabular}{|c|c|c|c|}
\hline No. & Drug Name & Latin Name & Part Used \\
\hline 1 & Musta & Cyprus rotundus Nust. & Dry Rhizome \\
\hline 2 & Aamalaki & Emblica officinalis Gaertn. & Dry Fruit \\
\hline 3 & Haritaki & Terminalia chebula Retz. & Dry Fruit \\
\hline 4 & Vibhitaki & Terminalia bellerica Roxb. & Dry Fruit \\
\hline 5 & Katuki & Picrorhiza kurroa Royle ex Benth. & Dry Root \\
\hline 6 & Kakamachi & Solanum nigrum Linn. & Dry Whole plant \\
\hline 7 & Kutaja & Holarrhena antidysenterica Wall. & Dry Bark \\
\hline 8 & Haridra & Curcuma longa Linn. & Dry Rhizome \\
\hline 9 & Vidanga & Embelia robusta Burm & Dry Fruit \\
\hline 10 & Guduchi & Tinospora cordifolia Willd. & Dry Stem \\
\hline 11 & Shweta Punarnava & Trianthema portulacastrum Linn. & Dry Root \\
\hline 12 & Sharapunkha & Tephrosia purpurea Linn. & Dry Root \\
\hline 13 & Apamarga & Achyranthus aspera Linn. & Dry Whole plant \\
\hline 14 & Kadali & Musa paradisiacal Linn, & Dry Rhizome \\
\hline 15 & Shatavari & Aspergus recemosus Willd. & Dry Root \\
\hline 16 & Shigru & Moringa oleifera Lam. & Dry Root bark \\
\hline 17 & Vasa & Adhatoda vasica Nees & Dry Leaves \\
\hline 18 & Daruharidra & Berberis aristata DC & Dry Root \\
\hline 19 & Sariva & Hemidesmus indicus R.Br. & Dry Root \\
\hline 20 & Manjishtha & Rubia cordifolia Linn. & Dry Root \\
\hline $21^{*}$ & Agnimantha & Clerodendrum Phlomidis.Linn. & Dry Root \\
\hline $22 *$ & Rohitaka & Tecomella undulate seem. & Dry Root \\
\hline $23 *$ & Agatsya & Sesbania grandifolia linn. & Leaves \\
\hline $24 *$ & Kumari & Aloe barbadensis Mill. & Leaves \\
\hline $25^{*}$ & Devadar & Cedrus deodara Roxb. & Dry Bark \\
\hline
\end{tabular}




\begin{tabular}{|l|l|l|l|}
\hline 21 & Madhu & Honey & ---- \\
\hline 22 & Sharkara & Saccharum officinarum Linn & Crystal \\
\hline 23 & Chaturjata & & \\
\hline & Twak & Cinnamomum zeylanicum Blume & Dry Bark \\
\hline & Ela & Elettaria cardamomum Maton & Dry Seed \\
\hline & Tamalapatra & Cinnamomum tamala Nees \& Eberm & Dry Leaf \\
\hline & Nagakesara & Mesua ferrea Linn & Dry Stamen \\
\hline 24 & Trikatu & & \\
\hline & Shunthi & Zingiber officinale Rosc. & Dry Rhizome \\
\hline & Maricha & Piper nigrum Linn. & Dry Fruit \\
\hline & Pippali & Piper longum Linn. & Dry Fruit \\
\hline
\end{tabular}

*Drug were added in Musta-Triphaladi Avaleha.

The test drug was prepared in the Pharmacy, Gujarat Ayurved University, Jamnagar, by following Standard Operating Procedures (S.O.P.) of preparation of Avaleha as practiced in the pharmacy. Avaleha is palatable for Children. No any preservative was added to the test drug. Drug preparation was finished on 07.01.2017. Finished product was stored in airtight, sterilized food grade plastic containers at room temperature under hygenic condition. Modified Musta Tiphaladi Avaleha administerd in the Thalassemia major children. It was necessary to prepare the formulation in a better dosage form which is also free from microbial contamination, stability of a pharmaceutical product is the capability of a perticular formulation in a specific container or closure system, to remail within its physical, chamical, microbiological therapeutic specifications. Thus in the present study on attempt was taken to check stability of avaleha with respect to its Microbial profile at different climacteric conditions and temperature setups at regular interval for a period of 1 year.

Aim: To study the microbial contamination in the finished product at different time interval at different climacteric conditions, temperature and humidity set ups.

Materials and Methods: Sample; of Modified Musta-Triphaladi Avaleha were prepared (stored at room temperature) and studied to check microbial contamination at regular intervals for a period of one year. Microbiological study has been carried out in Microbiology Laboratory, of Institute. Mainly 02 studies have been carried out to rule out that presence of any bacteria or fungi in the test drug. The initial microbiological study was done on second day of preperation, Before issuing to the patients. Then samples from containers were subjected to the microbilogical study regularly with random intervals during different seasons.

\section{Contents of Samples:}

The sample contents $1 \mathrm{gm}$ of Modified Musta Triphaladi Avaleha, 25 ingredients added with Honey \& Sarkara, also added Prakshepadravya used specific proportion of all contents it was followed by fix dosage form of Avaleha which will easier to take for children. The whole plant of Sharapunkha (Tephrosiapurpurea Linn.) was purchased from the local market and rhizomes of Kadali (Musa paradisiacal Linn.) were collected from the behind of pharmacy, GAU, Jamnagar and Agatsyapatra collect from Kodinar, Gujarat. other remaining drugs were provided by the raw drug store of Pharmacy. Agatsyapatra collected from Kodinar district, Gujarat.

Preparation Time: The drug was prepared in the Pharmacy, Gujarat Ayurved University, Jamnagar, by following Standard Operating Procedures (S.O.P.) of preparation of Avaleha as practiced in the pharmacy with the utmost caution to avoid any sort of contamination.

Date of preparation: 07 January 2017

Storage: Finished product of Modified MustaTriphaladi Avaleha was stored in air tight, sterilized food grade, plastic containers, smeared with ghee inside, stored in the open light area in the department at room temperature. Clean and dry stainless steel 
spoon was used to take medicine. After emptying the container $\mathrm{A}$, container $\mathrm{B}$ and $\mathrm{C}$ were used respectively in the same manner.

Microbial Profile: Microbial contamination was assessed by two methods to check any mycological findings and bacteriological findings.

\section{Smear Examination-}

A) Wet mount $/ 10 \%$ K.O.H. Preparation

B) Gram's stain

2. Culture Study-
A) Fungal culture

B) Aerobic culture

The details of the procedures followed are given below.

\section{Smear Examination:}

A. Wet mount $/ \mathbf{1 0 \%}$ K.O.H. Preparation (Chart No. 1\&2):

Aim: wet mount test for to rule out mycological findings in Avaleha

Specimen: As above mentioned

Chart 1: Procedure for Wet mount /10\% K.O.H. Preparation

\begin{tabular}{l} 
Take clean grease free glass slide \\
Put selected material \\
Cover with grease free cover glass \\
Add distilled water(if needed) \\
Observe under the high power (40x) lens \\
Report as per findings \\
\hline
\end{tabular}

Chart 2: Procedure For 10\% KOH Preparation

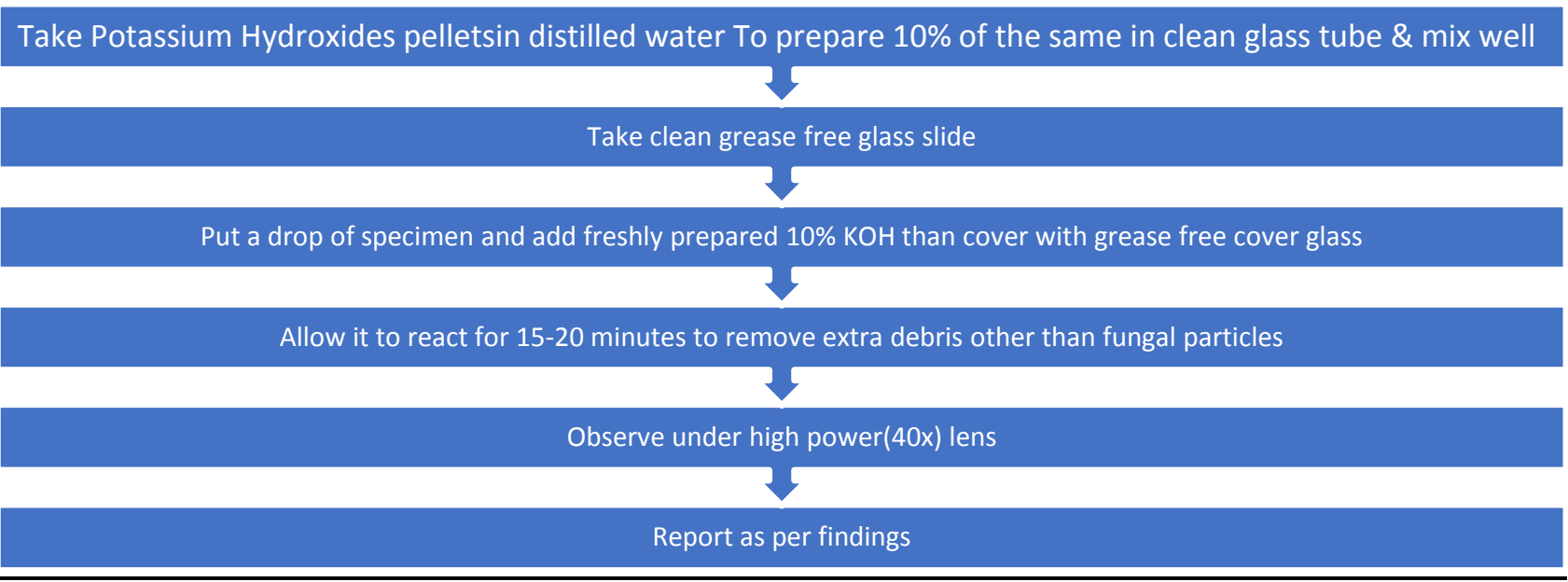

B. Gram's stain test (Chart No 3): Gram staining is a differential staining technique that differentiates bacteria into two groups: gram-positive and gramnegative. The procedure is based on the ability of mi- croorganisms to retain color of the stains used during the gram stain procedure. Gram negative bacteria are decolorized by any organic solvent (acetone or Gram's decolorizer) while Gram positive bacteria are 
not decolorized as primary dye retained by the cell and bacteria will remain as purple. After decolorization step, a counter stain effect found on Gram negative bacteria and bacteria will remain pink. The Gram stain procedure enables bacteria to retain color of the stains, based on the differences in the chemical and physical properties of the cell wall (Alfred E Brown, 2001) ${ }^{2}$

Aim: Gram's stain is to rule out any bacteriological findings from Avaleha.

Specimen: As Mentioned above
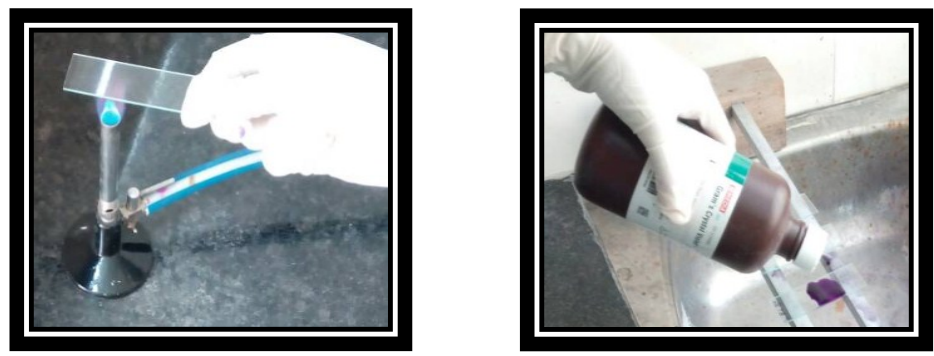

Figure 1 \& 2: Smear staining Procedure

Chart 3: Procedure For Gram's Stain

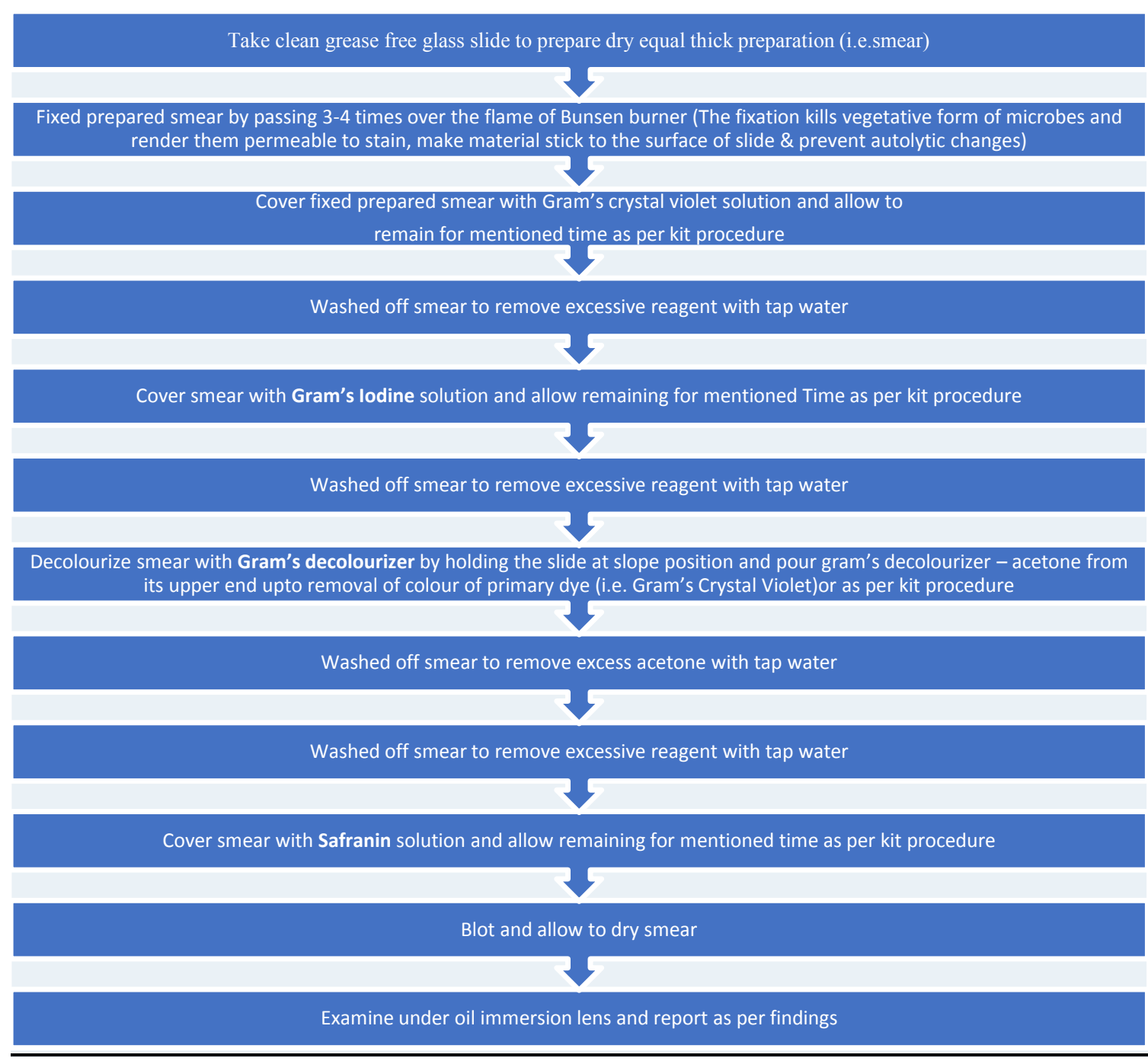




\section{Culture Study}

\section{A Fungal culture method as given in Chart No. 4:}

Respected materials collected with sterile cotton swab for inoculation purpose on selected fungal culture media (i.e. an artificial preparation). Name of media:
Sabouraud Dextrose Agar Base (SDA), Modified (Dextrose Agar Base, Emmons) Company: HIMEDIA Laboratories Pvt. Ltd., Required time duration: 05 to 07 days, required temperature: $37{ }^{\circ} \mathrm{C}$, Use of media: For selective cultivation of pathogenic fungi.

Figure 3: Sabouraud Dextrose Agar Base (SDA) bottle

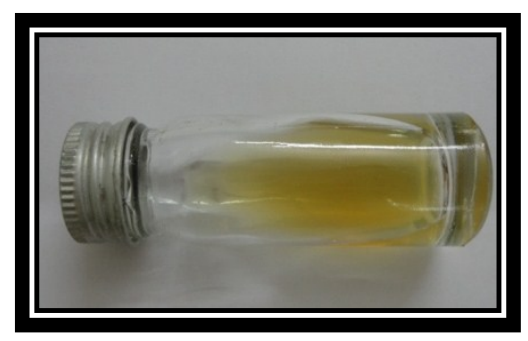

Chart 4: Procedure for Fungal Culture

In the clinical microbiology laboratory culture method are employed for isolation of organisms (The lawn / streak culture method is routinely employed)

Choose appropriate selective solid media for inoculation purpose

Dry selective solid media in Hot Air Oven before specimen inoculation

Allow to cool dried medium before Specimen inoculation

Inoculate selective specimen by Sterile cotton swab or by Nichrome wire (24 S.W.G.Size) loop [First sterile loop in

Bunsen burner oxidase flame-blue flame and aliow it cool than loop is charged with selected specimen to be cultured.Oneloopful of the specimen is transferrd onto the onto the surface of well dried culture medial

After inoculation / streaking process incubate inoculated medium in inverted position at $37^{\circ} \mathrm{c}$ for 05 to 07 to 21 days in incubator (incubation days are as per growth requirement) under aerobic atmosphere

After selected incubation period examined growth by nacked eye in form of colony or arial growth and confirm growth

by performing different related biochemical reactions and different related staining procedures.After that report isolates.

B. Aerobic culture method as given in Chart No. 5: Respected materials collected with sterile cotton swab for inoculation purpose on selected aerobic culture media (i.e. an artificial preparation)
Name of media: MacConkey Agar (MA) and Columbia Blood agar (BA)

Company: HIMEDIA Laboratories Pvt. Ltd.

Required time duration: 24 to 48 hours

Required temperature: $37^{\circ} \mathrm{C}$ 
Use of Media: for selective cultivation of pathogenic bacteria.

Figure 4: MacConkey Agar (MA)

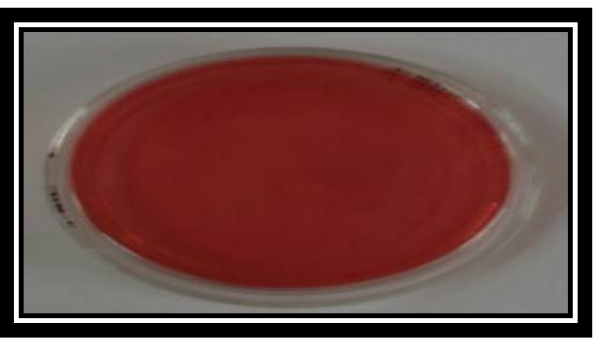

Chart No 5: Procedure for Aerobic Culture

In the clinical microbiology laboratory culture method are employed for isolation of organism (The streak culture method is routinely employed)

Choose appropriate selective solid media for inoculation purpose

Dry selective solid media in Hot Air Oven before specimen inoculation, Allow to cool dried medium before specimen inoculation

Inoculate selected specimen by four flame method (the loop should be flamed and cooled between the different sets of sreaks i.e. four time) on surface of cool dried medium with nichrome wire (24 S.W.G. size) loop [first sterile loop in Bunsen burner oxidase flame -blue flame and allow it to cool than loop is charged with selected specimen to be cultured. One loopful of the specimen is transferred onto the surface of well dried plate]

After streaking process incubate inoculated medium in inverted position at $37^{\circ} \mathrm{c}$ for $18-24$ hours in incubator under aerobic or $10 \% \mathrm{CO}_{2}$ atmosphere

After selected incubation period examined growth by nacked eye in form of colony and confirm growth by performing different related biochemical reactions and different related staining procedures. After that report isolates

Observations And Results Every time sample (in which drug preserved) were subjected to the microbiological study from the date of the preperation to the date of last microbiological study. 


\section{Observation are shown in Table 1.}

Table 1: Showing Observation of sample preserved at room temperature.

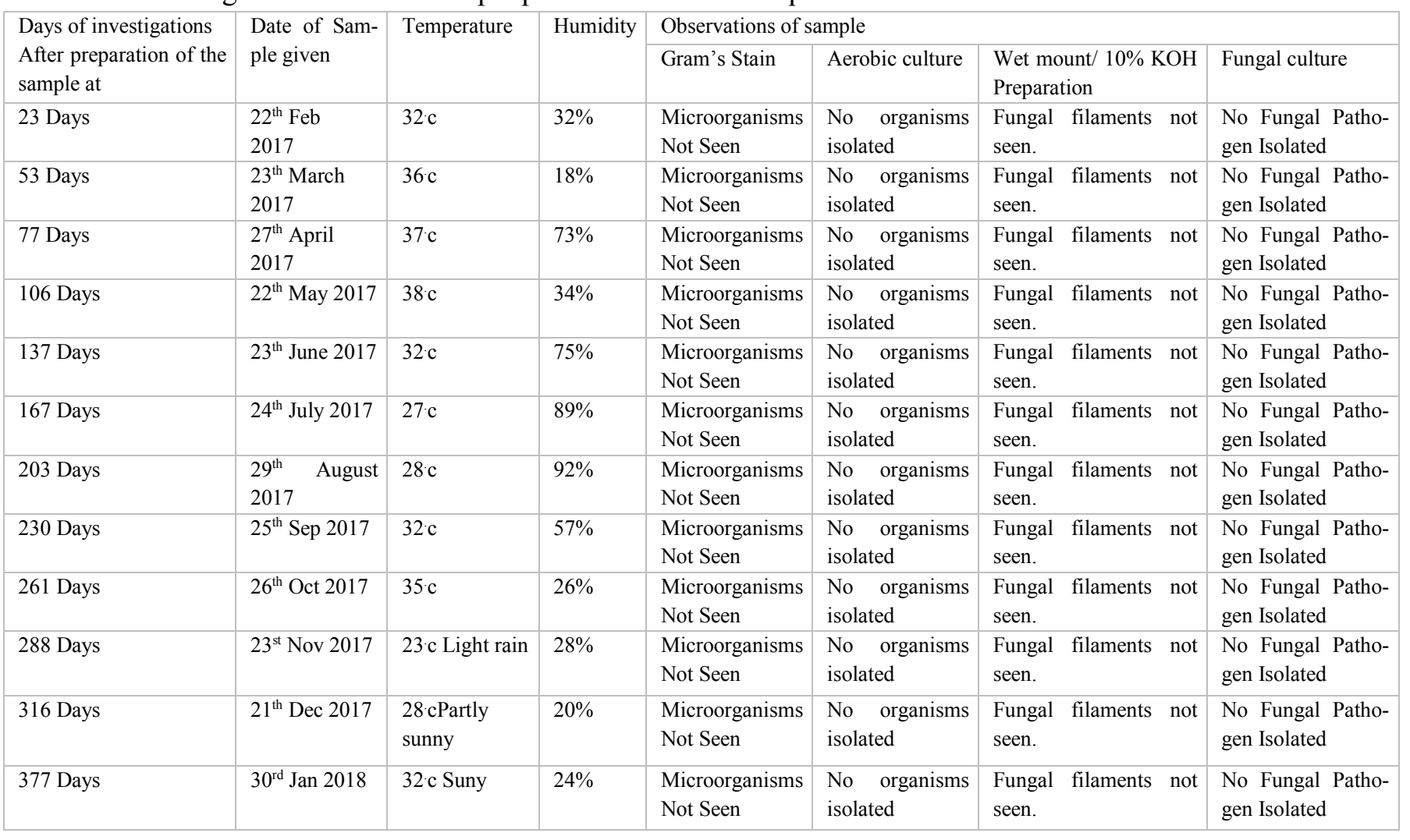

\section{DISCUSSION}

The unscientific methods of collection, storage, transportation and congenial climatic conditions to allow raw materials for herbal drugs prone to fungal $\&$ bacterial infestations. The raw materials collected using unscientific methods commonly exposed to many pathogenic contaminants and are often deteriorated by pathogenic microorganisms during handling and storage $^{3}$. Therefore, lack of regulation for herbal supplement presents potential health risk, largely their contamination chances with pathogenic. Present study was figured to observe the stability study of Modified Musta Triphaladi Avaleha with respect to Microbial Contamination of sample prepared and preserved in different climacteric and temperature conditions. Which has been used in Research work in IPGT \& RA in 2017 shows a very good and promising result in Thalassemia. It is needed to keep at safe place will be helpful for safe usage for a long time. Hence primary $10 \% \mathrm{KOH} /$ wet mount test was used; it detects fungal elements present but may not necessarily identify the species of the fungi. Gram's method of staining used to distinguish gram-positive bacteria and gramnegative bacteria. Aerobic \& Fungal Culture was also performed in every sitting. It studied at regular interval of 1 month for 1 year. At the end of study, it was observed all three containers were not showed presence of any Microbes.

\section{CONCLUSION}

Stability is usually expressed in term of Serviceable life, which is the time period from when the product is produced until the time it is intended to be consumed or used. Hence Microbiological study of the Modified Musta-triphaladi Avaleha showed that the quality of Avalehais in a standard condition. There were no growth found of microorganisms (Bacterial or fungal)till $30^{\text {st }}$ Jan 2018 i.e. 01 year from the date of preparation, shows its good shelf life. It can help in future for maintaining its optimum quality and safety 
and also provide guideline to the type of packaging and storage conditions.

\section{REFERENCES}

1. Agnivesh Charaka samhita of Acharya charaka, Dlhana krit Pratisansrit; sutrasthana ch.18;44-46; part 1 Varanasi Chaukhambha bharati Academy Prakasana; 2009.P.382.

2. Alfred E Brown (2001), Benson: Microbiological Application, $8^{\text {th }}$ Edition, the McGraw - Hill Companies, P. 64.

3. Dubey NK, Kumar A, Singh P, Shukla R. Microbial contamination of raw materials: A major reason for the decline of India's share in the global herbal market. Current Science 2008; 95(6): 717-718.

\section{Source of Support: Nil}

\section{Conflict of Interest: None Declared}

How to cite this URL: Bhumi Mori et al: Stability Study of Modified Musta-Triphaladiavaleha With Respect to BaseLine Microbial Profile Used in Thalassemia Major. International Ayurvedic Medical Journal \{online\} 2020 \{cited October, 2020 $\quad$ Available from: http://www.iamj.in/posts/images/upload/4578 4586.pdf 